\title{
The Morphological, Anatomical, And Physiological Characteristics of Elephantopus scaber As Explant Source For Tissue Culture
}

\author{
Yuliani $^{1}$, Sari Kusuma Dewi ${ }^{2}$, Fida Rachmadiarti ${ }^{3}$ \\ Department of Biology, Mathematics and Science Faculty, \\ Universitas Negeri Surabaya \\ Surabaya, Indonesia \\ 1yuliani@unesa.ac.id, ${ }^{2}$ saridewi@unesa.ac.id, ${ }^{3}$ fidarachmadiarti@unesa.ac.id
}

\begin{abstract}
The purpose of this study was to describe morphological characteristic (leaf area, plant height, and leaf sheath), to describe anatomical characteristic (trichomes found in leaf sheath, veins, leaf blade and stem, to describe the physiological characteristic from phytochemical tests of secondary metabolites from Elephantopus scaber leaf extract, to determine the correct explant source for tissue culture to avoid contamination and to cultivate good callus. The type of this study was descriptive. The study included morphological measurements of E. scaber sampled from Trawas, Mojokerto (midland $700 \mathrm{~m}-950 \mathrm{~m}$ above sea level). 20 leaves and leaf sheaths for were sampled for measurement of morphological characteristics. 20 plants were also sampled for height measurement. Morphological data described trichomes on leaf blade, veins, and leaf sheath. Microscopic observations of trichomes on leaf blade, veins, and leaf sheath were conducted to describe anatomical characteristics. Phytochemical content of the methanol extract of E. scaber plant leaves with various methods were conducted to describe physiological characteristics so the optimum explant source of the E. scaber could be determined. The results showed that $E$. scaber that lived in midlands had characteristics, ie average leaf area $=25.78 \mathrm{~cm}^{2}$, leaf sheath length $=1.86$ $\mathrm{cm}$ and plant height of $3.66 \mathrm{~cm}$, with needle-shaped non-glandular trichomes, and the leaves contained flavonoids, saponins, phenols and triterpenoids. The best explant source was found on the leaf bone which shows 11 specimens live two weeks after planting.
\end{abstract}

Keywords-Morphological Characteristics, Anatomy, Physiology, Elephantopus scaber, Explant Source, Tissue Culture

\section{INTRODUCTION}

Elephantopus scaber L. (Asteraceae) grows wild, often found on grass field, or on the roadside from lowlands to an altitude of 1200 meters above sea level (ASL). E. scaber has short and stiff stem with rough hair. Single leaves converge on the soil surface to form root rosette. The leaves are ellipticus, the edges are curved and jagged bluntly, the edges are blunt, the surface is rough haired, pinnate, the color is dark green. The flower stalk comes out from the middle of the rosette. Stem of its flower is stiff and tough, has long and rapid hair, branched and grooved [1] [2].

The plant Elephantopus scaber L. is a medicinal plant and has chemical contents which included flavonoids (methanol extract - leaf), phenols (methanol extract - leaf and rhizome), saponins (methanol extract, rhizome), steroids (methanol and chloroform extract - rhizome), tannins (chloroform extract leaf), terpenes (methanol and chloroform extract - leaf), triterpenoids, sesquiterpen lacton, elephantopin, triterpenes, and included epifriedelinol, lupeol, stigmasterol, lupeolacetate, deoxyelephantopin, isodeoxyelephantopin and luteolin-7glucoside, which acted as an antimicrobial [3] [4].

Li et.al. [5] and Wan Yong Ho et.al. [4] described that leaf and root of E. scaber in ethanol extract had antibacterial properties and could inhibit the growth of Bacillus subtilis, Stapphylococus aureus, E. coli, and Pseudomonas aeruginosa. It was also explained that Elephantopus scaber contained triterpenoids, stigmasterol, alkaloids, chalcon and phenol compounds.

Previous study [6], had developed biopesticides from $E$. scaber (tapak liman), Ageratum conyzoides (babandotan), and Pluchea indica (beluntas). The results showed that E. scaber was the most optimal plant for biopesticides. Leaf extract concentrations of 4 and $6 \%$ were able to effectively control Spodoptera litura mortality by $90 \%$ and Plutela xylostella mortality by $83.3-100 \%$ [7].

However, to be developed as pesticide in industrial scale (from E. scaber secondary metabolites), large amounts of leaves would be needed. As an illustration, $1 \mathrm{~kg}$ of wet leaves after dried only yield 200 grams and decreased when extracted (25 grams). Therefore another technique is needed for the multiplication of plant secondary metabolites by tissue culture techniques. Propagation by tissue culture techniques through callus formation could not only be used for plant production but also be used to produce chemical compounds resulted from secondary metabolism activities. According to Mulabagal [8], the level of secondary metabolite production in callus culture was higher than the level of production in the original plant. Jedinak [9] mentioned that the production of flavonoid compounds through tissue culture was more effective using callus culture, because with this method the production of glycosides and aglycones was more likely to be obtained than other tissue culture methods.

The formation of these compounds could occur based on biochemical totipotency, where a plant cell has a genetic potential derived to produce the same compound in large quantities if grown in in-vitro conditions [10]. Secondary metabolite compounds were obtained by extracting callus obtained from explants. Explant sources is very influential on the growth and morphogenesis of tissue culture, therefore 
optimum explant source is needed, in terms of growth, development, or endurance of contaminants.

E. scaber is a plant that has the potential to be developed in tissue culture techniques to isolate its secondary metabolites, and is used as a drug or biopesticide. Nevertheless, as a source of explants, E. scaber are very difficult to culture, because of the presence of trichomes found in the stem, leaf sheath, and even leaf blade. Planted explants were often contaminated with fungi and bacteria or if the sterilization technique was wrong, browning would occur. Therefore an exact description of E. scaber was needed, both in terms of growth or the presence of trichomes from various plant organs to make E. scaber as source of explants. This study described morphology (leaf area, plant height and leaf sheath), described anatomy (trichome type found on leaf sheath, veins, and leaf blade), described physiology of secondary metabolites contained in leaf with phytochemical test, and determined the correct explant source to avoid contamination so that the right explant source and good callus could be yield.

\section{METHODS}

The type of this study was descriptive. The first stage of the study included morphological measurements (length of leaf sheath and leaf area) of E. scaber plants sampled from Trawas Mojokerto area (midlands 700-950m ASL). All leaves from 20 plant specimens were measured then averaged (one plant had 5 leaves), as well as the leaf sheath length. Plant height was also measured from 20 specimens. The morphological data also described trichomes on leaves, leaf stems and leaf sheaths. The second stage was to describe anatomically the type of trichomes found in leaf sheath, leaf stem, and leaf blade by making microscope preparations. The third stage was to determine the phytochemical content of the methanol extract of E. scaber leaves with various methods, those were Culvenor-Fitzgerald alkaloid test, flavonoid test, saponin test, steroid test, triterpenoid test [11], and tanin test [12]. The fourth step determined the best source of explants from E. scaber that could be used in tissue culture. Before observation, explants were washed with detergent liquid and rubbed using soft brush. In the leaf sheath, leaf bone, and leaves that are covered with trichomes, trichomes were removed using knife. Clean explants were soaked in fungicides and bactericides for 30 minutes, then washed with running water and ready to be inoculated. Data were analyzed descriptively quantitative and qualitative.

\section{RESULTS AND DISCUSSION}

\section{A. Results}

a). Morphological characteristics (height, leaf area, and leaf sheath length) and the presence of trichome in plant organs

\section{Leaf Area}

TABLE I. LEAF AREA AVERAGE OF E. SCABER

\begin{tabular}{|c|c|c|c|c|c|c|}
\hline \multirow[b]{2}{*}{ Specimen } & \multicolumn{5}{|c|}{ Leaf area $\left(\mathrm{cm}^{2}\right)$} & \multirow{2}{*}{$\begin{array}{c}\text { Average } \\
\left(\mathrm{cm}^{2}\right)\end{array}$} \\
\hline & $\begin{array}{c}\text { Leaf } \\
1\end{array}$ & $\begin{array}{l}\text { Leaf } \\
2\end{array}$ & $\begin{array}{c}\text { Leaf } \\
3\end{array}$ & $\begin{array}{c}\text { Leaf } \\
4\end{array}$ & $\begin{array}{c}\text { Leaf } \\
5\end{array}$ & \\
\hline 1 & 35 & 32 & 18 & 22 & 28 & 27 \\
\hline 2 & 38 & 15 & 38 & 43 & 43 & 35.4 \\
\hline 3 & 10 & 15 & 13 & 20 & 18 & 15.2 \\
\hline 4 & 38 & 27 & 23 & 31 & 24 & 28.6 \\
\hline 5 & 34 & 46 & 46 & 47 & 40 & 42.6 \\
\hline 6 & 23 & 16 & 10 & 17 & 25 & 18.2 \\
\hline 7 & 33 & 20 & 14 & 18 & 11 & 19.2 \\
\hline 8 & 19 & 13 & 15 & 14 & 10 & 14.2 \\
\hline 9 & 23 & 24 & 27 & 20 & 14 & 21.6 \\
\hline 10 & 33 & 28 & 35 & 19 & 30 & 29 \\
\hline 11 & 42 & 46 & 27 & 27 & 32 & 34.8 \\
\hline 12 & 26 & 37 & 14 & 17 & 19 & 22.6 \\
\hline 12 & 43 & 31 & 20 & 48 & 46 & 37.6 \\
\hline 14 & 47 & 25 & 33 & 54 & 10 & 33.8 \\
\hline 15 & 15 & 31 & 9 & 41 & 36 & 26.4 \\
\hline 16 & 18 & 24 & 24 & 41 & 11 & 23.6 \\
\hline 17 & 16 & 44 & 30 & 40 & 40 & 34 \\
\hline 18 & 18 & 11 & 23 & 23 & 31 & 21.2 \\
\hline 19 & 11 & 11 & 14 & 29 & 14 & 15.8 \\
\hline 20 & 12 & 19 & 16 & 11 & 16 & 14.8 \\
\hline \multicolumn{6}{|c|}{ Average of leaf area for all specimens $\left(\mathrm{cm}^{2}\right)$} & 25.78 \\
\hline
\end{tabular}

The average leaf area of E. scaber plant was $25.78 \mathrm{~cm}^{2}$, with a leaf area of 14.8 to $42.6 \mathrm{~cm}^{2}$. Of the 20 specimens observed, the widest average leaf area $\left(42.6 \mathrm{~cm}^{2}\right)$ were found in specimen number 5 , while the smallest average $\left(14.8 \mathrm{~cm}^{2}\right)$ were found in specimen number 8 . Based on the average leaf area measured, it coulds be seen that each E. scaber plant had different leaf area, the older the age of the plant, the wider the leaf area.

\section{The length of the leaf sheath}

Morphometric data from the length of the leaf sheath were also measured starting from the base of the leaf to the boundary of the leaf bone. As for the observations of the average length of leaf sheath, different results were obtained from each measurement (Table II). Five leaves were measured for each specimen as a repetition. From 20 plants observed, the longest average leaf sheath was $2.7 \mathrm{~cm}$ while shortest average leaf sheath was $1.2 \mathrm{~cm}$. Based on the results of the average length of leaf sheath obtained, it could be seen that each specimen had different leaf sheath length, the average leaf sheath in all plants is $1.86 \mathrm{~cm}$ as in Table II. 
TABLE II. AVERAGE LENGTH OF E. SCABER LEAF SHEATH

\begin{tabular}{|c|c|c|c|c|c|c|}
\hline \multirow[b]{2}{*}{ Specimen } & \multicolumn{5}{|c|}{ Leaf sheath length $(\mathrm{cm})$} & \multirow{2}{*}{$\begin{array}{c}\text { Average } \\
\text { (cm) }\end{array}$} \\
\hline & $\begin{array}{c}\text { Leaf } \\
1\end{array}$ & $\begin{array}{c}\text { Leaf } \\
2\end{array}$ & $\begin{array}{c}\text { Leaf } \\
3\end{array}$ & $\begin{array}{c}\text { Leaf } \\
4\end{array}$ & $\begin{array}{c}\text { Leaf } \\
5\end{array}$ & \\
\hline 1 & 2 & 2.5 & 2 & 1 & 2,5 & 2 \\
\hline 2 & 2 & 2.5 & 2.5 & 2.5 & 2 & 2,3 \\
\hline 3 & 2 & 2 & 1,5 & 1,5 & 1,5 & 1,7 \\
\hline 4 & 1,5 & 1,5 & 1 & 2 & 2 & 1.6 \\
\hline 5 & 1,5 & 2 & 2 & 2 & 2,5 & 2 \\
\hline 6 & 3 & 2 & 2 & 2 & 2 & 2,2 \\
\hline 7 & 1 & 2 & 2 & 2 & 2,5 & 1,9 \\
\hline 8 & 2 & 2 & 2 & 2 & 2 & 2 \\
\hline 9 & 1,5 & 1,5 & 1,5 & 1 & 1 & 1,3 \\
\hline 10 & 2 & 2 & 1,5 & 1,5 & 2 & 1,8 \\
\hline 11 & 2 & 1,5 & 1,5 & 2 & 1,5 & 1,7 \\
\hline 12 & 2 & 1,5 & 2 & 1,5 & 1,5 & 1,7 \\
\hline 12 & 1 & 2 & 2 & 2 & 1,5 & 1,7 \\
\hline 14 & 1,5 & 2 & 2 & 2 & 2 & 1,9 \\
\hline 15 & 2 & 2 & 2 & 2 & 2 & 2 \\
\hline 16 & 3 & 3 & 2,5 & 2,5 & 2,5 & 2,7 \\
\hline 17 & 1 & 1 & 1,5 & 1,5 & 1 & 1,2 \\
\hline 18 & 2 & 2 & 2,5 & 2,5 & 2,5 & 2,3 \\
\hline 19 & 2 & 2 & 2 & 2 & 2 & 2 \\
\hline 20 & 1,5 & 1,5 & 1 & 1 & 1,5 & 1,3 \\
\hline \multicolumn{6}{|l|}{ Average 0} & 1,86 \\
\hline
\end{tabular}

\section{Plant height}

Plant height was measured from 20 specimens, as shown in table III.

TABLE III. Plant HeIGHT AVERAGE

\begin{tabular}{|c|c|}
\hline Specimen & height (cm) \\
\hline 1 & 3.5 \\
\hline 2 & 3.3 \\
\hline 3 & 3.4 \\
\hline 4 & 3.8 \\
\hline 5 & 3.3 \\
\hline 6 & 3,3 \\
\hline 7 & 4.5 \\
\hline 8 & 6 \\
\hline 9 & 5.5 \\
\hline 10 & 4 \\
\hline 11 & 4.5 \\
\hline 12 & 4 \\
\hline 13 & 5 \\
\hline 14 & 5 \\
\hline 15 & 3 \\
\hline 16 & 4 \\
\hline 17 & 3.75 \\
\hline 18 & 4 \\
\hline 19 & 2 \\
\hline 20 & 5 \\
\hline Average (cm) & 3.66 \\
\hline
\end{tabular}

From 20 plant specimen measured, the highest plant was $6 \mathrm{~cm}$, while the shortest plant was $2 \mathrm{~cm}$. Plant height did not have much different ranging from $2-6 \mathrm{~cm}$. Plant height differences were affected by plant age. The older the plant, the higher the size of the plant.

4. Observation of trichome morphology in plant organs

Based on morphological observations of E. scaber plants, it could be seen that trichomes were present in the stem and all parts of E. scaber leaves, those were on leaf sheaths, leaf bones, and the abaxial and adaxial part of leaf blade. Whereas in the root section trichomes were not found. The density between trichomes could be seen in the figures in Table IV.

TABLE IV. TRICHOMES MORPHOLOGY OBSERVATIONS ON E. SCABER

\begin{tabular}{|c|c|c|c|}
\hline $\begin{array}{l}\text { Plant } \\
\text { organ }\end{array}$ & $\begin{array}{l}\text { Trichome } \\
\text { Distribution }\end{array}$ & $\begin{array}{l}\text { Type of } \\
\text { trichome }\end{array}$ & Picture \\
\hline Root & Not found & - & \\
\hline $\begin{array}{l}\text { Stem } \\
\text { base }\end{array}$ & $\begin{array}{l}\text { Trichome } \\
\text { found in } \\
\text { every } \\
\text { segment of } \\
\text { stem in } \\
\text { upright } \\
\text { position } \\
\text { surrounding } \\
\text { stem nodes }\end{array}$ & $\begin{array}{l}\text { Non } \\
\text { Glandula } \\
\mathrm{r}\end{array}$ & \\
\hline $\begin{array}{l}\text { Stem } \\
\text { interno } \\
\text { des }\end{array}$ & $\begin{array}{ll}\text { Trichome } & \\
\text { found in all } \\
\text { surface } & \text { of } \\
\text { internodes } & \end{array}$ & $\begin{array}{l}\text { Non } \\
\text { Glandula } \\
\mathrm{r}\end{array}$ & \\
\hline $\begin{array}{l}\text { Stem } \\
\text { tip }\end{array}$ & \begin{tabular}{ll}
\multicolumn{2}{l}{ Trichome } \\
found in all \\
surface \\
stem tip
\end{tabular} & $\begin{array}{l}\text { Non } \\
\text { Glandula } \\
\mathrm{r}\end{array}$ & \\
\hline $\begin{array}{l}\text { Leaf } \\
\text { sheath }\end{array}$ & $\begin{array}{l}\text { Trichome } \\
\text { found dense } \\
\text { on the surface } \\
\text { of leaf sheath }\end{array}$ & $\begin{array}{l}\text { Non } \\
\text { Glandula } \\
\mathrm{r}\end{array}$ & \\
\hline $\begin{array}{l}\text { Leaf } \\
\text { bone/ } \\
\text { midrib }\end{array}$ & \begin{tabular}{ll}
\multicolumn{2}{l}{ Trichome } \\
found in all \\
surface \\
midrib of
\end{tabular} & $\begin{array}{l}\text { Non } \\
\text { Glandula } \\
\text { r }\end{array}$ & \\
\hline $\begin{array}{l}\text { Adaxia } \\
1 \text { side } \\
\text { of lef } \\
\text { blade }\end{array}$ & $\begin{array}{l}\text { Trichome size } \\
\text { varied and } \\
\text { spread in the } \\
\text { upper side of } \\
\text { leaf blade }\end{array}$ & $\begin{array}{l}\text { Non } \\
\text { Glandula } \\
\text { r }\end{array}$ & \\
\hline $\begin{array}{l}\text { Abaxia } \\
1 \text { side } \\
\text { of lef } \\
\text { blade }\end{array}$ & $\begin{array}{l}\text { Trichome } \\
\text { spread in the } \\
\text { upper side of } \\
\text { leaf blade }\end{array}$ & $\begin{array}{l}\text { Non } \\
\text { Glandula } \\
\mathrm{r}\end{array}$ & 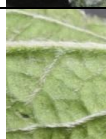 \\
\hline
\end{tabular}


Trichomes were found on the tip of the stem, the stem nodes, the stem base, leaf sheath, leaf bone, and abaxial and adaxial side of leaf blade. Trichomes were non-glandular, characterized by the presence of coarse hair that does not produce secretions. Trichomes were present in the form of fine spines that caused the leaves to be coarse textured and were not preferred by herbivores.

b). Trichome anatomical characteristics of E. scaber stem and leaf

The results of anatomical observations showed that trichomes found on the surface of the E. scaber plant have unicellular and non-glandular cell type. The cross section preparations showed ordinary hair-shaped trichome because the cells did not contain special liquids secreted, recycled or excreted. Trichomes could be observed in Table V.

TABLE V. ANATOMICAL CROSS SECTION OF E. SCABER TRICHOME

\begin{tabular}{|l|l|l|l|}
\hline $\begin{array}{l}\text { Plant } \\
\text { organ }\end{array}$ & $\begin{array}{l}\text { Trichome } \\
\text { Type }\end{array}$ & $\begin{array}{l}\text { Trichome } \\
\text { Shape }\end{array}$ \\
\hline Stem & $\begin{array}{l}\text { Non } \\
\text { Glandular }\end{array}$ & $\begin{array}{l}\text { Simple } \\
\text { needle-like } \\
\text { hairs }\end{array}$ & Picture \\
\hline $\begin{array}{l}\text { Scales } \\
\text { on } \\
\text { nodes }\end{array}$ & $\begin{array}{l}\text { Non } \\
\text { Glandular }\end{array}$ & $\begin{array}{l}\text { Simple } \\
\text { needle-like } \\
\text { hairs }\end{array}$ & \\
\hline $\begin{array}{l}\text { Base of } \\
\text { leaf } \\
\text { bone/ } \\
\text { midrib }\end{array}$ & $\begin{array}{l}\text { Non } \\
\text { Glandular } \\
\text { sheath }\end{array}$ & $\begin{array}{l}\text { Non } \\
\text { Glandular }\end{array}$ & $\begin{array}{l}\text { Simple } \\
\text { needle-like } \\
\text { hairs } \\
\text { hairs }\end{array}$ \\
\end{tabular}

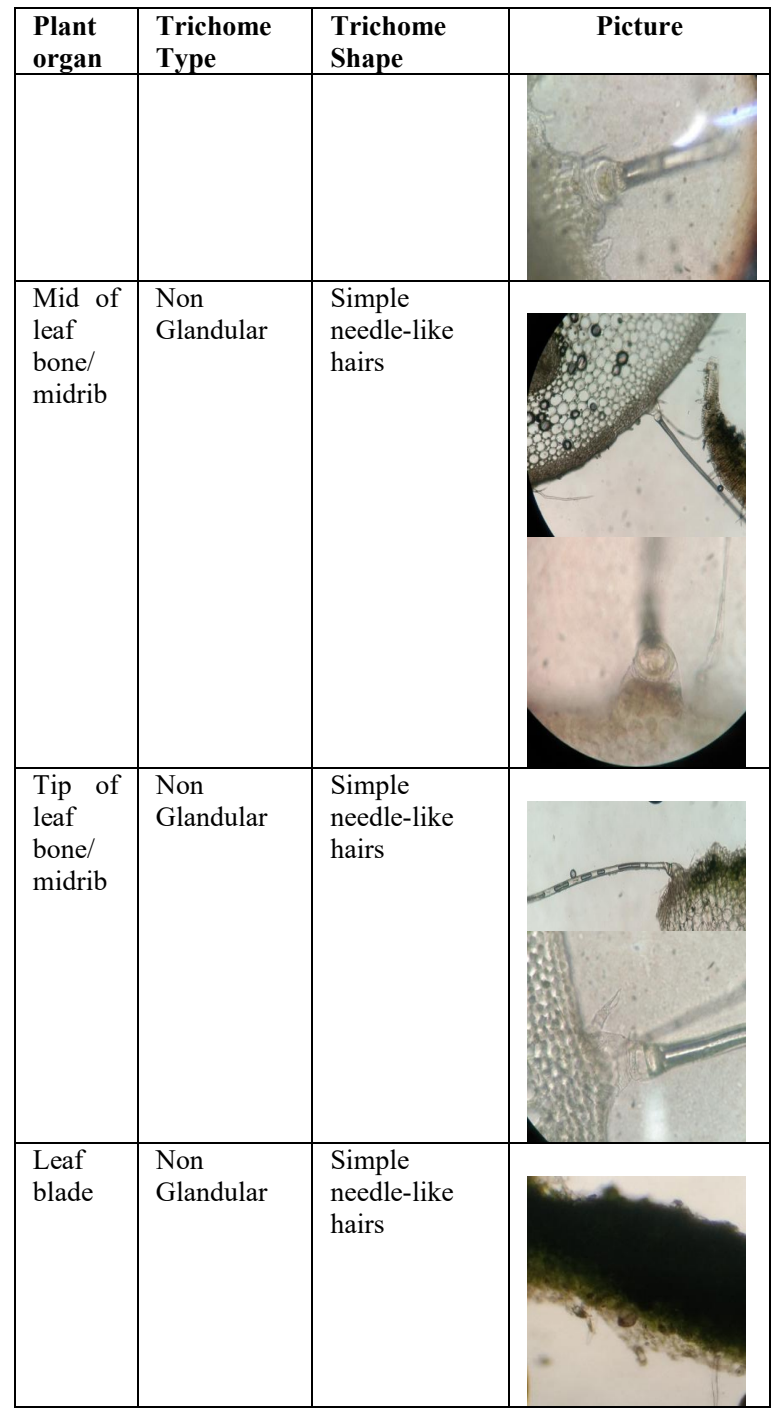

All trichomes observed were non-glandular trichomes. Trichome is a development of the epidermis, epidermal cells form the structure of hair that protrudes outward [13]. In this study trichomes shaped like needles. Trichome has a function in reducing the intensity of sunlight and protecting plants from predators.

c). Physiological Characteristics of E. scaber leaf

Physiological characteristics of E. scaber was obtained from phytochemical tests (secondary metabolites) methanol extract of its leaves.

TABLE VI. RESULT OF PHYTOCHEMICAL TEST ON E. SCABER LEAF

\begin{tabular}{|l|l|l|}
\hline Identifier & Test result & Conclusion \\
\hline Alkaloid & \multicolumn{2}{|c|}{ Negative } \\
\hline Dragendorff & $\begin{array}{l}\text { Green turbid } \\
\text { solution, white } \\
\text { sediment was not } \\
\text { formed }\end{array}$ & \\
\hline Wagner & $\begin{array}{l}\text { Brown Solution, } \\
\text { brown sediment was } \\
\text { formed }\end{array}$ & \\
\hline Mayer & Greenish-brown & \\
\hline
\end{tabular}




\begin{tabular}{|c|c|c|}
\hline Identifier & Test result & Conclusion \\
\hline & $\begin{array}{l}\text { solution, } \quad \text { orange } \\
\text { sediment was not } \\
\text { formed }\end{array}$ & \\
\hline Flavonoid & $\begin{array}{l}\text { Reddish-brown } \\
\text { solution }\end{array}$ & Positive \\
\hline Saponin & $\begin{array}{l}\begin{array}{l}\text { Stable foam } \\
\text { formed }\end{array} \\
\text { was }\end{array}$ & Positive \\
\hline Steroid & Brown solution & Negative \\
\hline Triterpenoid & $\begin{array}{l}\text { Two layers were } \\
\text { formed, upper layer } \\
\text { had brownish color }\end{array}$ & Positive \\
\hline Tannin & $\begin{array}{l}\text { Dark green solution, } \\
\text { sediment was not } \\
\text { formed }\end{array}$ & Negative \\
\hline Phenolic & Black brown color & Positive \\
\hline
\end{tabular}

Phytohemical test results showed that E. scaber leaves contained secondary metabolites of flavonoids, saponins, triterpenoids, phenolics and did not contain alkaloids, steroids and tannins. From these four secondary metabolites, E. scaber has the potential as a biopesticide or medicinal plant.

d). Determination of the exact source of explants from the $E$. scaber

Based on the presence of trichomes in E. scaber, it was very difficult to make $E$. scaber as an explant source even though the secondary metabolite content was quite rich. Therefore various sources of explants suitable for tissue culture to produce a good callus were tested. The explant sources used were leaf blade, leaf sheath, and leaf bone. The explants were treated to eliminate trichomes pre-inoculation. Based on tissue culture study with the addition of $0.04 \mathrm{mg} / \mathrm{L}$ 2.4-D and $0.02 \mathrm{mg} / \mathrm{L}$ kinetin growth hormones, the observation result was showed in Table VII.

The results of the tissue culture trial showed that the explants taken from leaf bone had higher percentage of life compared to leaf sheath and leaf blade. This was explained in Table VII which showed that out of 20 pieces of leaf sheath explant there were no live explants on 2 weeks after inoculation, but there were still 11 live explants from leaf bone and 1 live explant from leaf blade.

TABLE VII. EXPLANT GROWTH TAKEN FROM LEAF BLADE, LEAF SHEATH, AND LEAF BONE OF E. SCABER WITH ADDITION OF SELECTED GROWTH HORMONE 2 WEEKS AFTER INOCULATION

\begin{tabular}{|l|l|l|l|l|l|}
\hline \multirow{2}{*}{$\begin{array}{c}\text { Incubation } \\
\text { time } \\
\text { (week) }\end{array}$} & \multicolumn{5}{|c|}{ Leaf sheath explant } \\
\cline { 2 - 6 } & Total & Live & Browning & \multicolumn{2}{|l|}{ Contamination } \\
\cline { 2 - 6 } & & & & B & F \\
\hline 0 & 40 & 40 & - & - & - \\
\hline 1 & 40 & 18 & 10 & 12 & - \\
\hline 2 & 40 & - & 14 & 23 & - \\
\hline & \multicolumn{5}{|l|}{} \\
\hline & Leaf bone explant & & - & - & - \\
\hline 0 & 40 & 40 & - & 15 & 4 \\
\hline 1 & 40 & 21 & - & 23 & 6 \\
\hline 2 & 40 & 11 & - & - & - \\
\hline & Leaf blade explant & 7 & 17 \\
\hline 0 & 40 & 40 & - & 9 & 25 \\
\hline 1 & 40 & 10 & 6 & 5 & \\
\hline 2 & 40 & 1 & 5 & \\
\hline
\end{tabular}

Note:

B : Contaminant source from bacteria

F : Contaminant source from fungi

\section{B. Discussion}

Secondary metabolites were synthesized by plants. Most of them function as phytoalexin, an antibody to defend itself when the plant experienced external disturbances such as an attack of pathogens, pollution, heavy metals, changes in temperature or ultraviolet radiation [14]. E. scaber leaf contained secondary metabolites of flavonoids, saponins, triterpenoids, phenolics (table VI), which could function as medicines, biopesticides and antibacterials. However, the level of secondary metabolites production in plant tissues was relatively low (less than $1 \%$ plant dry weight) and was very dependent on physiological conditions and stages of plant development [15] [16]. One strategy to improve the content of secondary metabolites was through plant tissue culture techniques, which had several advantages compared to conventional methods, one of which could form bioactive compounds under controlled conditions and in a relatively short time. To produce secondary metabolites, suspension culture and callus culture were commonly used [8] [17].

Callus formation was affected by the supply of exogenous hormones. Among the hormones that could affect callus formation are auxins and cytokines. Other factors that influenced callus formation were genotypes, explant physiological conditions, nutritional composition of the growth medium, and endogenous content of hormones (auxins and cytokines) [18] [19].

Physiological conditions of explants greatly affected the formation of callus. Observation of morphological characteristics indicated that the growth of E. scaber was very good in terms of leaf area, leaf sheath or plant height. The average leaf area is $25.78 \mathrm{~cm}^{2}$, the length of the leaf sheath is $1.86 \mathrm{~cm}$ and the plant height is $3.66 \mathrm{~cm}$ (table I, II, and III). Plant growth was influenced by internal factors (hormones and genes), also by external factors or environment such as light, temperature, humidity, soil, and altitude. Altitude of land affected climatology (climate) and edaphic (soil) in the habitat of plant growth [20]. Good growth indicated that cell growth and meristem tissue needed for totipotency processes also goes well. The source of explants needed to be free of pests and diseases, so they must be sterile. E. scaber plants morphologically and anatomically have very dense trichomes. Non-glandular trichome presented in form of protruding outward and needle-shaped hair. Trichomes had a defense function for plants but it could be habitats for microbes, so that when used as a source of explants, leaves that have a lot of trichomes were very susceptible to be host for contaminants (both bacteria and fungi). Therefore in the source of explants, trichomes must be removed and explants must be sterilized.

Sterilization in tissue culture consisted of sterilization of equipment, media sterilization, practitioner sterilization, explant sterilization and sterilization of laboratory. Sterilization played important role in maintaining the condition of the culture to be free from contamination of the disease both from bacteria, fungi, and viruses. Shofiyani and 
Hajoeningtijas [21] mentioned that sterilization was the initial stage of callus culture activities that had important role in the success of providing sterile explants. The sterilization method used with the precision of the method, material, and time would determine the success of the sterilization process [22].

Based on the results of preliminary study of tissue culture, it was obtained that the most suitable explant source was found in the leaf bone. On the leaf bone, trichomes were not as thick as on the leaf blade. In the leaf bone there was also a transport vessel so that the diffusion process of nutrient osmosis from culture medium also took place well. Nutrients for explants in addition to growth into callus, could also be used to improve explant resistance to microbes.

\section{CONCLUSION}

The results of this study indicate that:

1. Elephantopus scaber plants lived in midlands have following morphological characteristics, ie average leaf area $=25.78 \mathrm{~cm}^{2}$, length of leaf sheath $=1.86 \mathrm{~cm}$ and plant height of $3.66 \mathrm{~cm}$.

2. Elephantopus scaber plants had needle-shaped nonglandular trichomes.

3. Elephantopus scaber plants contained secondary metabolites, those are flavonoids, saponins, phenols and triterpenoids, which could be used as medicinal plants or biopesticides.

4. The most suitable explant source for tissue culture was leaf bone which showed 11 lived plants two weeks after inoculation.

\section{REFERENCES}

[1] Steenis, Van, C.G.G.J, Flora for Schools in Indonesia. Jakarta: PT. Pradnya Paramita, 1992.

[2] Heyne, K., Tumbuhan Berguna Jilid III Cetakan ke-1. Jakarta: Badan Litbang Kehutanan Jakarta, 1987.

[3] Mohan,V.R.,P.Chenthurpandy and Kalidass, 'Pharmacognostic and Phytochemical Investigation of E. scaber L.(Asteraceae) " Journal of Pharmaceutical Science and Technology, vol. 2, no. 3, 2010, pp. 191197.

[4] Wan Yong Ho, Huynh Ky, Swee Keong Yeap, Raha Abdul Rahim, Abdul Rahman Omar ,Chai Ling Ho and Noorjahan Banu Alitheen,"Traditional Practice, Bioactivities and Commercialization Potential of E. scaber Linn". Journal of Medicinal Plants Research, vol 3 no.13, 2009, pp.1212-1221.
[5] Li,Wang, Shuguang Jian, Peng nan, and Yang Zhong, 'Chemical Composition of the Essential Oil of E. scaber from Southern China" Naturforsch,vol 59c, 2004, pp. 327-329.

[6] Yuliani,'Kajian Senyawa Fenolik dari Tumbuhan Asteraceae pada Berbagai Ketinggian Habitat sebagai Pengendali Spodoptera litura Fab." unpublished, Malang: Universitas Brawijaya, 2015.

[7] Yuliani, Lisa Lisdiana," Pengembangan Biopestisida dari Flora Lokal untuk meningkatkan Kualitas Agroekosistem Sawah padi Organik“" Surabaya: LPPM Universitas Negeri Surabaya, 2015.

[8] Mulabagal,'Plant cell culture - an alternative and efficient source for the production of biologically important secondary metabollites", International Journal of Applied Science and Engineering, vol. 2, no.1, 2004, pp. 29-48.

[9] Jedinak, A., J. Farago, I. Psenakova, and T. Maliar. 2004, 'Approaches to flavonoid production in plant tissue cultures "'Biologia, Bratislavia, vol. 59, no.6, 2004, pp. 697-710.

[10] Lestari, Endang G, 'Peranan Zat Pengatur Tumbuh dalam Perbanyakan Tanaman melalui Kultur Jaringan',Jurnal AgroBiogen, vol. 7, no.1, 2011, pp. 63-68.

[11] Harborne, J.B.,' Phytochemical Methode ',London:Chapman and Hall ltd, 1987.

[12] Edeoga,H.O.,D.E.Okw,B.O.Mbaebie,'PPhytochemical Constituens of some Nigerian Medicinal Plant",African Journal of Biotechnology,vol. 4, no.7, 2005, pp. 685-688.

[13] Fahn,A.,'Plant Anatomy“',England: Pergamon Press Ltd,1982.

[14] Dixon, R.A and N.L. Paiva,' 'Stress induced phenylpropanoid metabolism“'. The Plant Cell,vol.7, 1995, pp.1085-1097.

[15] $\mathrm{Yu} \mathrm{O}$. and Brian $\mathrm{M}$, “'Metabolic engineering of isoflavone biosynthesis'،. Journal of Experimental Botany,vol. 52,no.357.2003.pp. 681-689.

[16] Taiz, L. dan E. Zeiger,'Plant Physiology", 3rd Edition, Sinauer Assiociated. USA,2002.

[17] Robins R. J." Secondary Product from Cultured Cell Culture and Organs: I. Mollecular and Cellular Approach. Plant Cell Cultures. A Practical Approach''. Second edition, Oxford University press. New York.1994,pp.169-198.

[18] Chawla,'Plant Tissue Culture : Theory and Practice', A Revised Edition.1996.

[19] George, E.F. and P.D. Sherington, 'Plant Propagation by Tissue Culture. Handbook and Directory of Commercial Laboratories'. Exegetic. England,1984.

[20] Yuliani,Soemarno, Bagyo Yanuwiadi and Amin Setyo Leksono.2015 'The Relationship between Habitat Altitude, Enviromental Factors and Morphological Characteristics of Pluchea Indica, Ageratum Conyzoides and Elephantopus scaber. " OnLine Journal Of Biological Sciences.Science Publication, vol. 15, no. 3, 2015,pp.143-151.

[21] Shofiyani, Anis dan Oetami Dwi Hajoeningtijas," Pengaruh Sterilan dan Waktu Perendaman pada Eksplan Daun Kencur (Kaemferia galanga L) untuk Meningkatkan Keberhasilan Kultur Kalus", Agritech, vol.12,no.1, 2010,pp.11-29.

[22] Manzanilla, Lijia,'Surface Sterilization for the Establishment In-Vitro of Cassava (Manihot esculenta). 'Thesis. Department of Science Faculty of Science and Technology University of Belize. 2010. 